\title{
An Unusual Complication in Johanson's Staged Urethroplasty: Squamous Cell Carcinoma
}

\author{
Gaurav Garg, Siddharth Pandey*, Deepanshu Sharma, Samarth Agarwal, Ajay Aggarwal, Ashish Sharma, Kaushal \\ Gupta and Satyanarayan Sankhwar
}

Department of Urology, King George's Medical University, India

Submission: June 28, 2018; Published: July 13, 2018

*Corresponding author: Siddharth Pandey, Department of Urology, King George’s Medical University, Lucknow, India, Email: sid1420@gmail.com

\begin{abstract}
Urethral stricture is an uncommon urological condition in developing countries like India. It usually results from trauma, iatrogenic injuries and venereal infections. Penile carcinoma is a common genital cancer with usual risk factors being phimosis, human papillomavirus (HPV) infection, tobacco smoking, sexual promiscuity and poor hygiene. The occurrence of carcinoma in penile stump following Johannson's staged urethroplasty for anterior urethral stricture is extremely rare. Herein, we report a rare delayed occurrence of squamous cell carcinoma in the penile stump following Johannson's staged urethroplasty for anterior urethral stricture in a circumscribed man.
\end{abstract}

\section{Introduction}

Stricture urethra and penile carcinoma are two urological conditions which have a major impact on patient's quality of life[1,2].However, their association is not well described till date. The occurrence of carcinoma penis in circumscribed males is fairly uncommon. Multiple treatments of urethral stricture combined with human papilloma virus (HPV) infection may result in premalignant changes that may subsequently lead to squamous cell carcinoma of the penis. This case pertains to an unusual complication occurring during prolonged management of urethral stricture.

\section{Case Presentation}

A 66-year-old Muslim man presented with a history of slowly increasing painless growth over the penile shaft for 2-months. The patient had a history of anterior urethral stricture about 3 years back for which he underwent multiple endoscopic visual urethrotomy \& urethral dilations followed by Johannson stage I urethroplasty year back. There was no history suggestive of any trauma, drug addiction or sexually transmitted diseases. He had undergone circumcision during infancy. He denied any history of tobacco chewing or smoking. On clinical examination, there was firm non tenderexophytic growth of size $4 \mathrm{~cm} \mathrm{X} 4 \mathrm{~cm}$ involving the entire penile shaft(Figure 1\&2) with no enlargement of inguinal lymph nodes. The growth was highly suspicious for malignancy and a wedge incisional biopsy was planned from the growth and surrounding penile tissue. Routine blood and urine investigations were normal. Chest X-ray was unremarkable. HPV testing was not done as routine testing for HPV is not

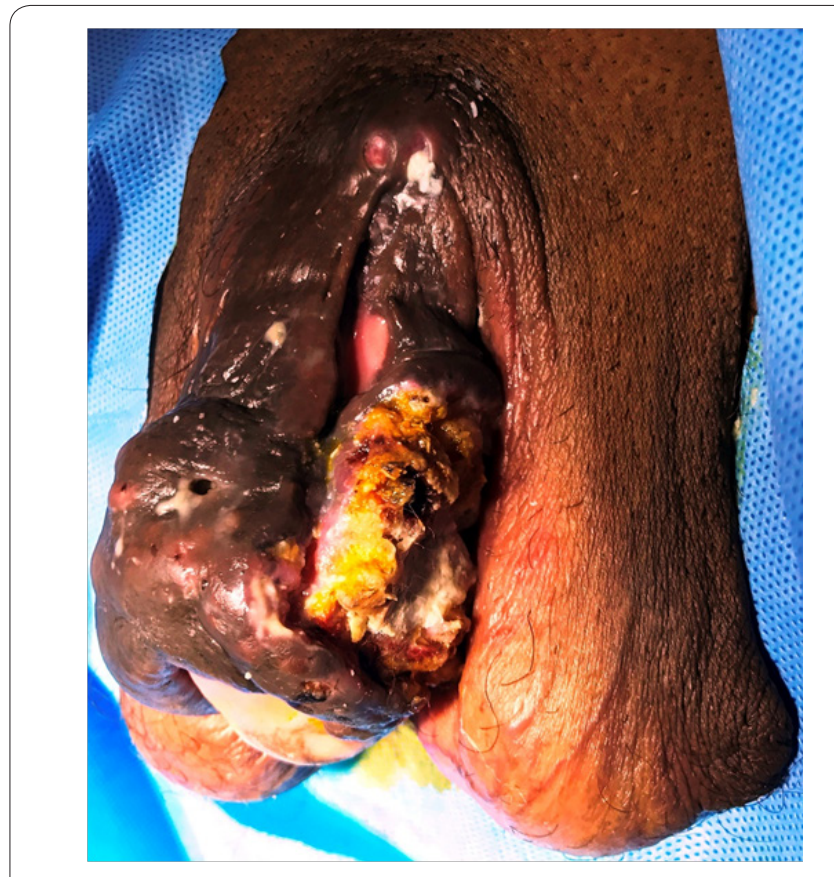

Figure 1: Image showing an exophytic growth arising from the penis.

performed at our institution.The wedge biopsy results were suggestive of well-differentiated squamous cell carcinoma of the penis. As the growth was involving the whole of the shaft and due to inability to achieve sufficient penile stump with negative margins, the patient was counselled for total penectomy. The 
final histopathology analysis revealed moderately differentiated squamous cell carcinoma involving the urethra, penile skin, and underlying subepithelial tissue, with a $1-\mathrm{cm}$ free surgical margin(Figure 3). The patient had a long hospital stay of 15 days for management of local infection of his wound. The patient was advised strongly for elective bilateral inguinal lymph node dissection at 1-month follow-up, but he denied. At present (follow up of 3 months), the patient is doing well \& there are no inguinal lymph nodes palpable in the groin.Informed Consent was obtained from patient for publication.

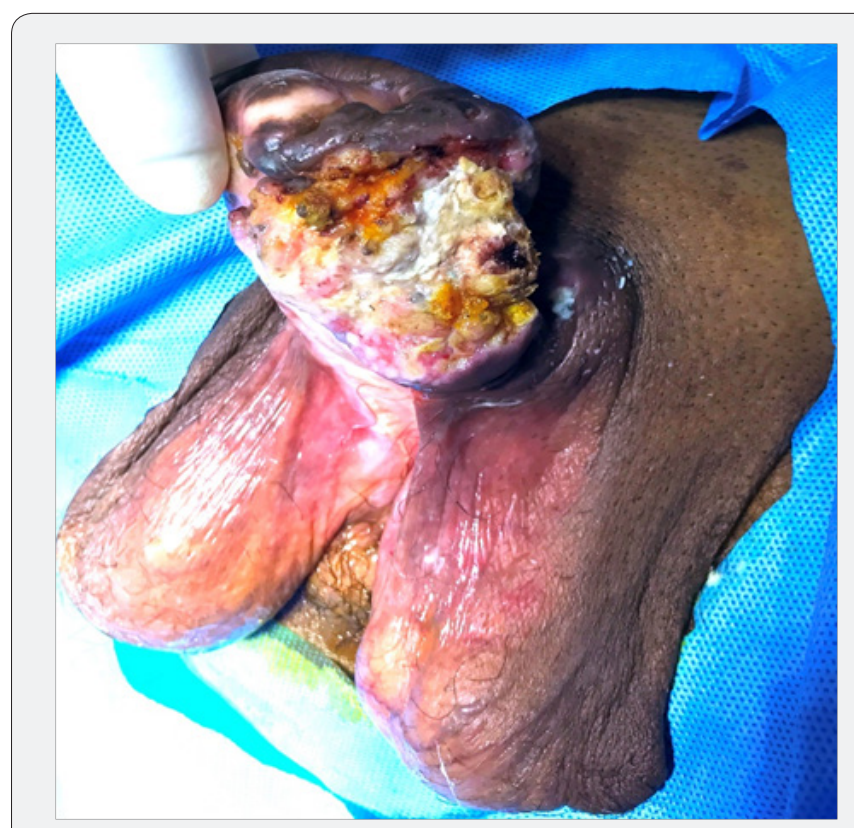

Figure 2: image showing growth involving whole of the shaft of penis.

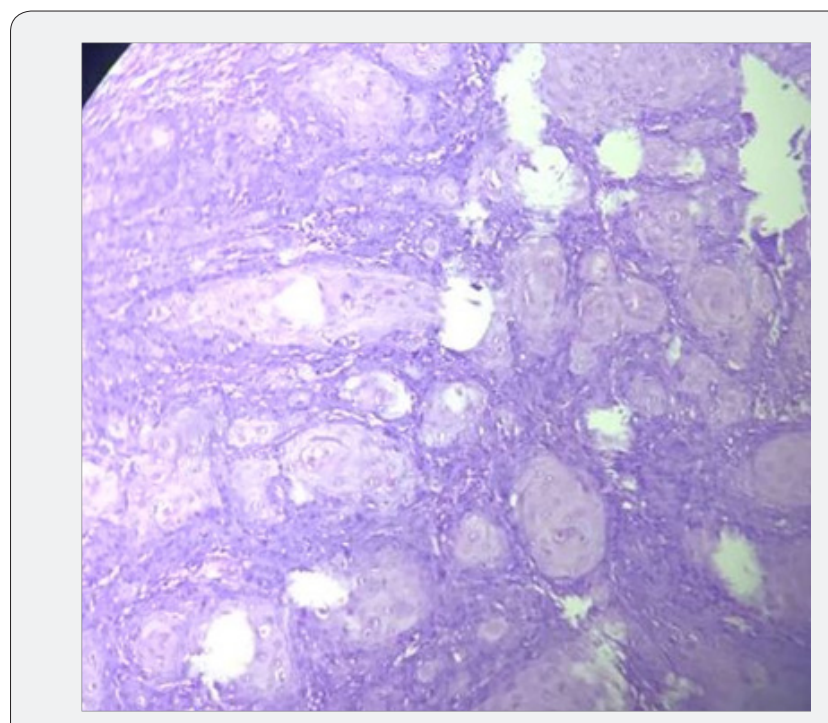

Figure 3: Image showing malignant epithelial cells disposed of in sheets and clusters. Individual atypical cells are pleomorphic with high nucleocytoplasmic ratio, hyperchromatic nuclei, inconspicuous nucleoli and a moderate amount of cytoplasm. Occasional keratin pearls are also seen (H \& E 40 X).

\section{Discussion}

Penile cancer is a common male cancer in developing countries like India with known risk factors such as phimosis, human papillomavirus (HPV) infection, tobacco smoking, sexual promiscuity,poor hygiene and low socio-economic status[3]. However, the occurrence of penile carcinoma in patients with long standing urethral stricture is very rare. Till date, only 4 studies have reported the occurrence of penile cancer in patients of urethral stricture[4-7].Kathpalia et al. [4]reported the development of verrucous penile carcinoma in a76-year-old uncircumscribed man fourmonths after undergoing repeated urethral dilatation for bulbar urethral stricture. The patient was managed by partial penectomy[4]. The authors postulated that HPV may play a role as a causative factor in both urethral stricture and penile carcinoma[4]. Malik et al. [5] reported about a 55-year-old man, who underwent total penectomy for a fungating growth over the penis that was initially diagnosed as a case of bulbar urethral stricture \& was managed by visual urethrotomy and after a span of three months[5]. The authors proposed that sexually transmitted diseases, especially herpetic infections, may be implicated as an aetiological factor in both diseases[5]. Ahmed et al. [6]reported a case of a 55-year-old man who developed ventral penile masses and scrotal wall swelling after 5 years of repeated urethral dilatation done for bulbar urethral stricture[6]. The lesion was diagnosed as well differentiated penile carcinoma \&pseudoepitheliomatoushyperplasia (PEH) and it was managed by total penectomy with scrotectomy[6]. Taneja et al.[7]reported development of squamous cell carcinoma of penis 10 years after patient received treatment for pan anterior urethral stricture[7]. The authors postulated that presence of balanitis xerotica obliterans(BXO) may be a premalignant factor leading to development of carcinoma penis later on in urethral stricture patients[7]. In the present case a 66-year old circumscribed male who underwent repeated treatments for stricture urethra in the span of 3 years developed carcinoma penis. Our case was unique in the extent that the patient was circumscribed during infancy and there were no risk factors or pre-malignant conditions in our patient. It is unlikely that association of long standing urethral stricture and carcinoma penis is merely co-incidental. We can hypothesize that repeated treatments of urethral stricture disease with coexisting latent HPV infection may have lead to pre-malignant changes resulting in development of carcinoma penis later on. The Centers for Disease Control and Prevention (CDC) does not recommend routine screening for HPV in men as there is lack of standardised test and effective therapy for established infection[8]. Although our patient was circumscribed, and HPV testing was not done it has been shown previously that latent HPV infection is present in most of sexually active males[9]. HPV has been implicated in around $48 \%$ of penile cancers and it is proposed that oncogenic potential of HPV persists despite undergoing neonatal circumcision $[9,10]$. The only possible method to prevent HPV infection is vaccination against HPV 
(especially type 16 and 18)[11]. Hence, it is suggested that sexually active men who have long-standing history of urethral stricture should undergo routine vaccination against HPV. Thus, it is essential to recognize penile cancer early in the clinical setting.Routine follow up and biopsy of suspicious lesions is warranted for early diagnosis.

\section{Consent}

Proper consent was taken from the patient.

\section{References}

1. Lubahn JD, Zhao LC, Scott JF, Hudak SJ, Chee J, et al. (2014) Poor quality of life in patients with urethral stricture treated with intermittent selfdilation. J Urol 191(1): 143-147.

2. Maddineni SB, Lau MM, Sangar VK (2009) Identifying the needs of penile cancer sufferers: a systematic review of the quality of life, psychosexual and psychosocial literature in penile cancer. BMC Urol 9: 8 .

3. Christodoulidou M, Sahdev V, Houssein S, Muneer A (2015) Epidemiology of penile cancer. Curr Probl Cancer 39(3): 126-136

4. Kathpalia R, Goel A, Singh BP (2011) Urethral skip metastasis from cancer penis or a second malignancy? A dilemma! Int Braz J Urol 37(5): 657-658.

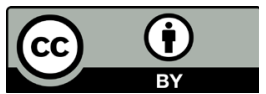

This work is licensed under Creative Commons Attribution 4.0 License DOI: 10.19080/JOJCS.2018.07.555721
5. Malik GA (2008) Unusual presentation of carcinoma of penis. J Coll Physicians Surg Pak 18(1): 40-42.

6. Kotb AF, Attia D, Ismail AM, Elabbady A (2013) Squamous cell carcinoma on top of urethral stricture: case report and review of the literature. Ecancermedicalscience 7: 304.

7. Taneja Y, Ram P, Dhaked SK, Sen TK (2017) Squamous Cell Carcinoma Penis in a Case of Urethral Stricture Due to Lichen Sclerosus Balanitis Xerotica Obliterans: A Case Report and Review of Literature. J Clin Diagn Res 11(7): PD17-PD18.

8. Centers for Disease Control and Prevention. HPV and men. CDC Fact Sheet.

9. Backes DM, Kurman RJ, Pimenta JM, Smith JS (2009) Systematic review of human papillomavirus prevalence in invasive penile cancer. Cancer Causes Control 20(4): 449-457.

10. Saibishkumar EP, Crook J, Sweet J (2008) Neonatal circumcision and invasive squamous cell carcinoma of the penis: a report of 3 cases and a review of the literature. Can Urol Assoc J 2(1): 39-42.

11. Giuliano AR, Palefsky JM, Goldstone S, Moreira ED Jr, Penny ME, et al. (2011) Efficacy of quadrivalent HPV vaccine against HPV Infection and disease in males. N Engl J Med 364(5): 401-411.

\section{Your next submission with Juniper Publishers will reach you the below assets}

- Quality Editorial service

- Swift Peer Review

- Reprints availability

- E-prints Service

- Manuscript Podcast for convenient understanding

- Global attainment for your research

- Manuscript accessibility in different formats

( Pdf, E-pub, Full Text, Audio)

- Unceasing customer service

Track the below URL for one-step submission https://juniperpublishers.com/online-submission.php 